\title{
A PRELIMINARY PROPULSIVE PERFORMANCE EVALUATION FOR AN OIL TANKER TO MEET THE EEDI CHALLENGE
}

\author{
Mihaela Amoraritei \\ University "Dunarea de Jos" of Galati, \\ Faculty of Naval Architecture, Galati, \\ Domneasca Street, No. 47, 800008, Romania, \\ E-mail:mihaela.amoraritei@ugal.ro
}

\begin{abstract}
To control $\mathrm{CO}_{2}$ emissions from ships, the International Maritime Organization (IMO) has introduced a mandatory technical measure for new ships: the Energy Efficiency Design Index (EEDI). The paper presents a preliminary evaluation of the propulsive performances for a 30000 tdw oil tanker, complying with the EEDI regulations. Ship resistance and propulsive power have been computed and several main diesel engines have been selected. For every study case, an optimal efficiency propeller has been designed and the Energy Efficiency Design Index has been calculated.
\end{abstract}

Keywords: Energy Efficiency Design Index (EEDI), ship propulsion performances

\section{INTRODUCTION}

Maritime transport is an important source of air pollution. In 2015, the ships involved in international trade contributed with about $2.6 \%$ to global $\mathrm{CO}_{2}$ emissions [1]. To control $\mathrm{CO}_{2}$ emissions from shipping, the International Maritime Organization (IMO) has introduced a mandatory technical measure for new ships: the Energy Efficiency Design Index (EEDI).

As a measure of the ship energy efficiency, EEDI can be expressed as $\mathrm{CO}_{2}$ emissions versus transport work. The $\mathrm{CO}_{2}$ emissions are influenced by the installed power of the main and auxiliary engines as well as the quality and quantity of fuel burned in them. The transport work is expressed according to two important parameters in the EEDI formula: speed and ship capacity. Energy Efficiency Design Index is focused mainly on less pollutant equipments and has a significant impact on the ship propulsion system design and in the whole ship design process.
The paper presents a preliminary study of propulsive performances for a 30000-tdw oil tanker, complying with the EEDI regulations. According to the data provided by the International Council of Clean Transportation Report [1], oil tankers are responsible for $13 \%$ from the total shipping $\mathrm{CO}_{2}$ emissions (Figure1).

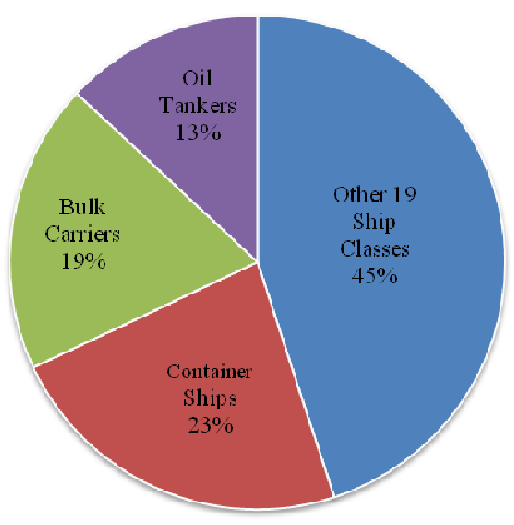

Fig.1. Shipping $\mathrm{CO}_{2}$ emissions 
In the present study, ship resistance and propulsive power have been computed and several main diesel engines have been selected. For every case study, an optimal efficiency propeller has been designed and the Energy Efficiency Design Index has been calculated.

\section{SHIP PROPULSIVE PER- FORMANCE EVALUATION}

The present study has been focused on the design of the propulsion system for a 30000-tdw oil tank, with the following main dimensions:

$$
\begin{array}{lrr}
\text { Length on the waterline } & 173.65 & {[\mathrm{~m}]} \\
\text { Breadth } & 26 & {[\mathrm{~m}]} \\
\text { Design draught } & 10.5 & {[\mathrm{~m}]}
\end{array}
$$

Ship resistance, effective power and necessary propulsive power have been computed. Effective power defined as ship resistance multiplied with ship speed has been plotted in Figure 2.

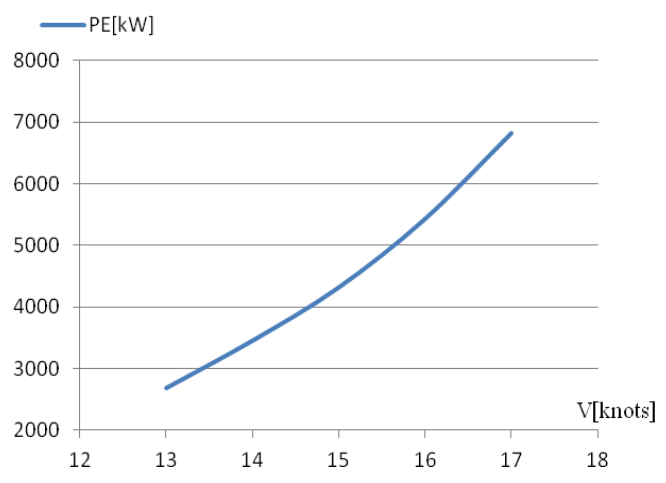

Fig.2. Effective power

Six slow Diesel engines have been selected for tanker propulsive performances investigations. For every case study an optimal four-bladed propeller has been designed to absorb minimum power and to give maximum efficiency. The propellers have been designed taking into consideration $15 \%$ SM (Sea Margin) and 10\% EM (engine margine). The results regarding propeller charac- teristics and ship performances are presented in Tables 1-6.

Table 1. Ship/propeller propulsive performances - case 1,2

\begin{tabular}{|l|c|}
\hline \multicolumn{2}{|c|}{ Cases 1, 2 } \\
\hline \multicolumn{2}{|c|}{ Engine } \\
\hline Power [kW] & 6950 \\
\hline Speed [rpm] & 111 \\
\hline Number of cylinders & 5 \\
\hline \multicolumn{2}{|c|}{ Propeller } \\
\hline Diameter [m] & 6 \\
\hline Pitch ratio P/D & 0.69 \\
\hline Blade area ratio & 0.5 \\
\hline Efficiency Ship \\
\hline \multicolumn{2}{|c|}{ Sh } \\
\hline Ship speed [knots] & 13.95 \\
\hline
\end{tabular}

Table 2. Ship/propeller propulsive performances - case 3

\begin{tabular}{|l|c|}
\hline \multicolumn{2}{|c|}{ Case 3 } \\
\hline \multicolumn{2}{|c|}{ Engine } \\
\hline Power [kW] & 6950 \\
\hline Speed [rpm] & 130 \\
\hline Number of cylinders & 5 \\
\hline \multicolumn{2}{|c|}{ Propeller } \\
\hline Diameter [m] & 5.47 \\
\hline Pitch ratio P/D & 0.675 \\
\hline Blade area ratio & 0.55 \\
\hline Efficiency Ship \\
\hline \multicolumn{2}{|c|}{0.535} \\
\hline Ship speed [knots] & 13.75 \\
\hline
\end{tabular}

Table 3. Ship/propeller propulsive performances - case 4

\begin{tabular}{|l|c|}
\hline \multicolumn{2}{|c|}{ Case 4 } \\
\hline Engine \\
\hline Power [kW] & 8340 \\
\hline Speed [rpm] & 130 \\
\hline Number of cylinders & 6 \\
\hline \multicolumn{2}{|c|}{ Propeller } \\
\hline Diameter [m] & 5.63 \\
\hline Pitch ratio P/D & 0.694 \\
\hline Blade area ratio & 0.58 \\
\hline Efficiency Ship \\
\hline \multicolumn{2}{|c|}{ Sh } \\
\hline Ship speed [knots] & 14.59 \\
\hline
\end{tabular}


Table 4. Ship/propeller propulsive performances - case 5

\begin{tabular}{|l|c|}
\hline \multicolumn{2}{|c|}{ Ease 5 } \\
\hline \multicolumn{2}{|c|}{ Engine } \\
\hline Power [kW] & 6810 \\
\hline Speed [rpm] & 146 \\
\hline Number of cylinders & 6 \\
\hline \multicolumn{2}{|c|}{ Propeller } \\
\hline Diameter [m] & 5.11 \\
\hline Pitch ratio P/D & 0.66 \\
\hline Blade area ratio & 0.58 \\
\hline Efficiency & 0.5153 \\
\hline \multicolumn{2}{|c|}{ Ship } \\
\hline Ship speed [knots] & 13.51 \\
\hline
\end{tabular}

Table 5. Ship/propeller propulsive performances - case 6

\begin{tabular}{|l|c|}
\hline \multicolumn{2}{|c|}{ Case 6 } \\
\hline \multicolumn{2}{|c|}{ Engine } \\
\hline Power [kW] & 5675 \\
\hline Speed [rpm] & 146 \\
\hline Number of cylinders & 5 \\
\hline \multicolumn{2}{|c|}{ Propeller } \\
\hline Diameter [m] & 4.95 \\
\hline Pitch ratio P/D & 0.648 \\
\hline Blade area ratio & 0.55 \\
\hline Efficiency & 0.5096 \\
\hline \multicolumn{2}{|c|}{ Ship } \\
\hline Ship speed [knots] & 12.78 \\
\hline
\end{tabular}

Table 6. Ship/propeller propulsive performances - case 7

\begin{tabular}{|l|c|}
\hline \multicolumn{2}{|c|}{ Case 7 } \\
\hline \multicolumn{2}{|c|}{ Engine } \\
\hline Power [kW] & 6090 \\
\hline Speed [rpm] & 167 \\
\hline Number of cylinders & 5 \\
\hline \multicolumn{2}{|c|}{ Propeller } \\
\hline Diameter [m] & 4.615 \\
\hline Pitch ratio P/D & 0.637 \\
\hline Blade area ratio & 0.6 \\
\hline Efficiency Ship & 0.4864 \\
\hline \multicolumn{2}{|c|}{} \\
\hline Ship speed [knots] & 12.87 \\
\hline
\end{tabular}

\section{CALCULATION OF THE EN- ERGY EFFICIENCY DESIGN INDEX}

In a simplified formula, the Energy Efficiency Design Index (EEDI) can be expressed as $\mathrm{CO}_{2}$ emissions versus transport work.

EEDI $=\frac{\mathrm{CO}_{2} \text { Emission }}{\text { TransportWork }}$

The $\mathrm{CO}_{2}$ emissions are given by the main and auxiliary engines power multiplied by the $\mathrm{CO}_{2}$ conversion factor and the specific fuel consumption. The transport work is expressed as ship speed multiplied by ship capacity. The formula is more complex, $\mathrm{CO}_{2}$ emission reduction due to innovative technologies may be added at numerator and different coefficients are used for particulars situations (i.e. the weather factor, the capacity correction factors, etc).

The power of the main engines $\mathrm{P}_{\mathrm{ME}}[\mathrm{kW}]$ is $75 \%$ of the rated installed power (MCR) and the auxiliary power $\mathrm{P}_{\mathrm{AE}}$ are taken as a fixed proportion of the main engine power (i.e. $5 \% \mathrm{MCR}$ for $\mathrm{MCR}<10000 \mathrm{~kW}$ ) [2],[3]. The $\mathrm{CO}_{2}$ conversion factor is a nondimensional factor between fuel consumption and the $\mathrm{CO} 2$ emissions depending on the fuel type (i.e. for Diesel/Gas oil $\mathrm{C}_{\mathrm{F}}=3.206$ ). The specific fuel consumption $\mathrm{SFC}[\mathrm{g} / \mathrm{kWh}]$ is defined as quantity of fuel use per unit of engine power and may be found in the engine Technical File. SFC for main engine is generally taken at $75 \%$ load and for auxiliary engines is generally taken at $50 \%$ load. Capacity depends on the ship type, i.e. for oil tanker, the deadweight should be used for capacity. Ship speed [knots] is an important parameter in the ship propulsive performance analysis with a significant impact on EEDI regulations.

The attained EEDI, computed using IMO guidelines, has to be below the required EEDI specific to the ship type and size. A reference line (base line) is defined as: 


$$
\text { REF.Line }=a * \text { Capacity }^{-c}
$$

where parameters $a$ and $c$ are given depending on the ship type: for oil tanker: $\mathrm{a}=$ 1218.8 and $\mathrm{c}=0.488$.

The required EEDI has to be reduced based on the reference line (Phase 0) by percents each five years, depending on the ship types. For oil tankers with size in DWT between 4000 and 20000 and above, the \% reductions in Required EEDI relative to Reference line are presented in Table 7.

Table 7. Reduction factor in \% for the Required EEDI for oil tanker

\begin{tabular}{|c|c|c|}
\hline & \multicolumn{2}{|c|}{ Oil tanker size [DWT] } \\
\hline & $4000-20000$ & $\begin{array}{c}20000 \text { and } \\
\text { above }\end{array}$ \\
\hline $\begin{array}{c}\text { Phase 0 } \\
(2013-2014)\end{array}$ & - & - \\
\hline $\begin{array}{c}\text { Phase 1 } \\
(2015-2019)\end{array}$ & $0-10$ & 10 \\
\hline $\begin{array}{c}\text { Phase 2 } \\
(2020-2024)\end{array}$ & $0-20$ & 20 \\
\hline $\begin{array}{c}\text { Phase 3 } \\
(2025-)\end{array}$ & $0-30$ & 30 \\
\hline
\end{tabular}

Six main engines have been chosen, but the case numbering has been made according to the EEDI calculation. An engine with the same power/speed [rpm] characteristics has been selected for cases 1 and 2, but in the second case, EEDI has been computed using for fuel consumption the values obtained when the engine and turbocharger are matched to the lowest possible SFOC values while fulfilling the IMO Tier III emission limits [4].

The results regarding the attained EEDI have been plotted in Figures 3-9, to verify the computed values in comparison with the reference line and the required EEDI corresponding to Phase 2 (2020-2024). In Table 8, the results regarding the attained EEDI have been centralized and the EEDI reduction from the EEDI base line versus ship speed has been analyzed.

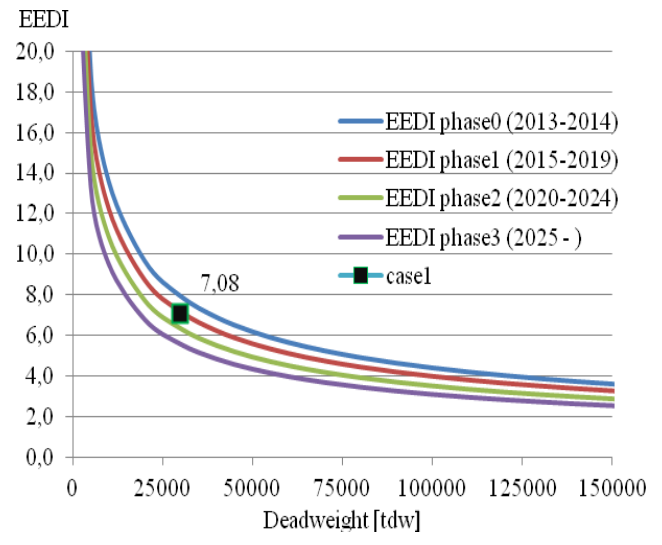

Fig.3. EEDI verification Case 1

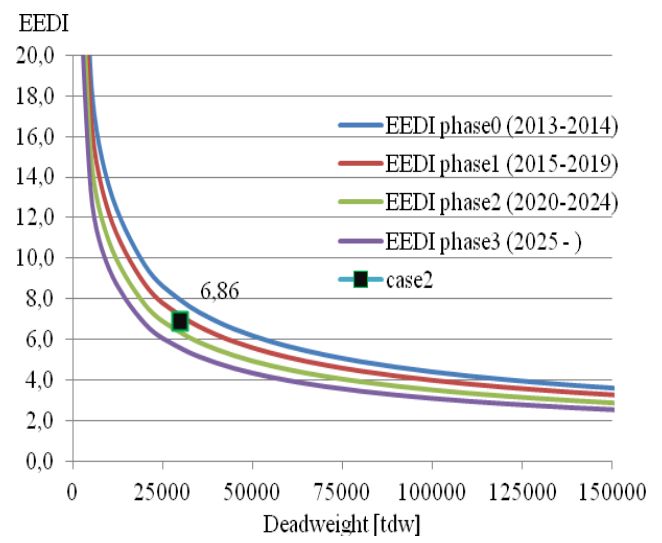

Fig.4. EEDI verification Case 2

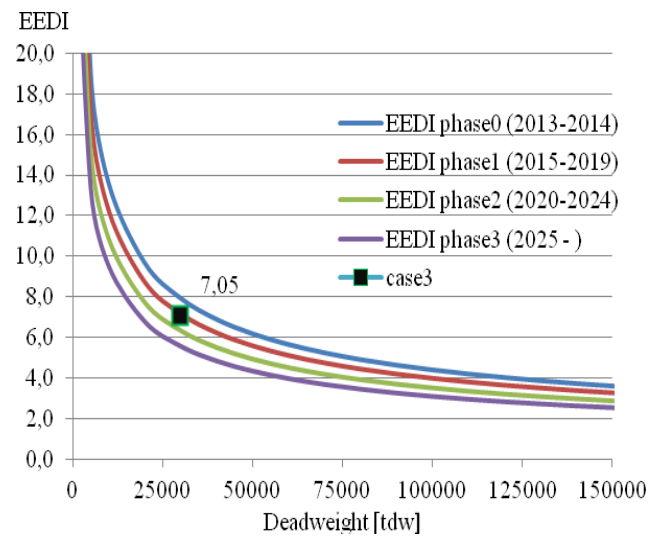

Fig.5. EEDI verification Case 3 


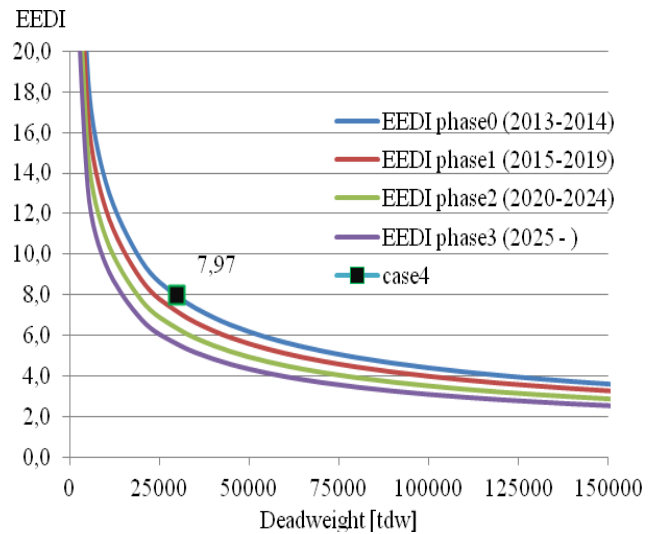

Fig.6. EEDI verification Case 4

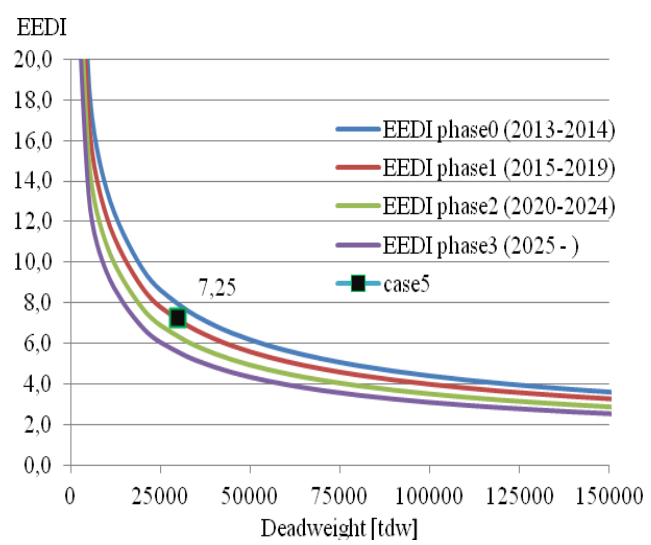

Fig.7. EEDI verification Case 5

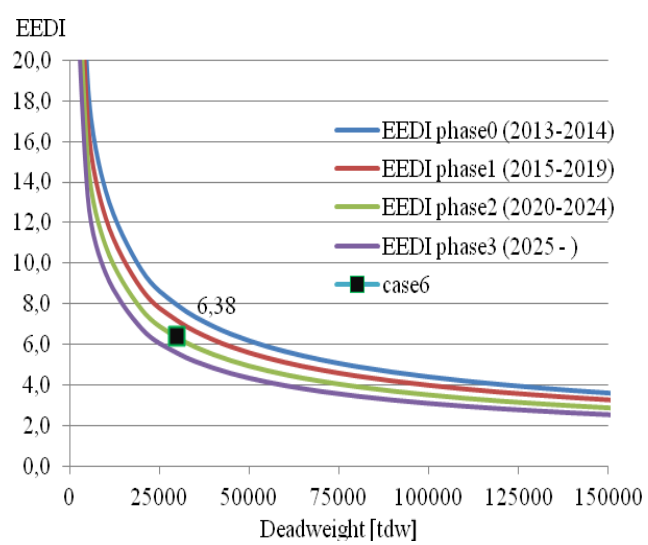

Fig.8. EEDI verification Case 6

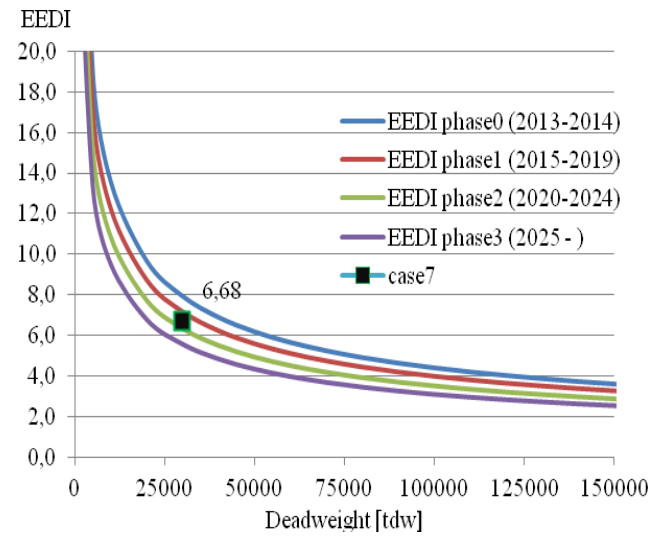

Fig.9. EEDI verification Case 7

Table 8. Attained EEDI and \% reduction relative to reference line versus ship speed

\begin{tabular}{|c|c|c|c|c|}
\hline $\begin{array}{l}\mathbb{0} \\
\tilde{z} \\
\tilde{E}\end{array}$ & 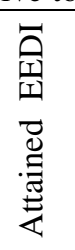 & $\begin{array}{c}\% \text { reduc- } \\
\text { tion rela- } \\
\text { tive to } \\
\text { reference } \\
\text { line }\end{array}$ & $\begin{array}{l}\text { Required } \\
\text { EEDI } \\
\text { Phase } 2 \\
\text { (20\% } \\
\text { reduction } \\
\text { factor) }\end{array}$ & $\begin{array}{l}\text { Ship } \\
\text { speed } \\
\text { [knots] }\end{array}$ \\
\hline 1 & 7.08 & $11.30 \%$ & 6,371 & 13,95 \\
\hline 2 & 6.86 & $13.86 \%$ & 6,371 & 13,95 \\
\hline 3 & 7.05 & $11.47 \%$ & 6,371 & 13,75 \\
\hline 4 & 7.97 & $-0.13 \%$ & 6,371 & 14,59 \\
\hline 5 & 7.25 & $8.99 \%$ & 6,371 & 13,5 \\
\hline 6 & 6.38 & $19.83 \%$ & 6,371 & 12,78 \\
\hline 7 & 6.68 & $16.10 \%$ & 6,371 & 12,87 \\
\hline
\end{tabular}

The data regarding engine power versus attained EEDI has been plotted in the diagram from Figure 10. The results regarding ship speed (obtained with the optimal efficiency designed propeller) versus attained EEDI have been plotted in Figure 11.

The best ship speed performance has been obtained with the higher power engine (case 4), but this was the worst case from the EEDI point of view. In the case studies, there was no EEDI reduction of $20 \%$ below the base line (corresponding to Phase 2, 20202024). With the lower power engine (case 6), the EEDI have been reduced by $19.83 \%$ below the EEDI reference line, but the ship speed is far from the propulsive performance 
expectation. With the most efficient combination main engine/propeller (cases 1 and 2), EEDI have been reduced with $11.3 \%$, $13.86 \%$ respectively. In these case studies, the ship speed (obtained with the optimal efficiency designed propeller) was close to the required speed. Higher propeller efficiency has been obtained for higher propeller diameter and lower rpm. In case 2, the EEDI reduction was more pronounced due to fuel oil consumption values while fulfilling the IMO Tier III emission limits, under the same power/ speed/ship capacity conditions.

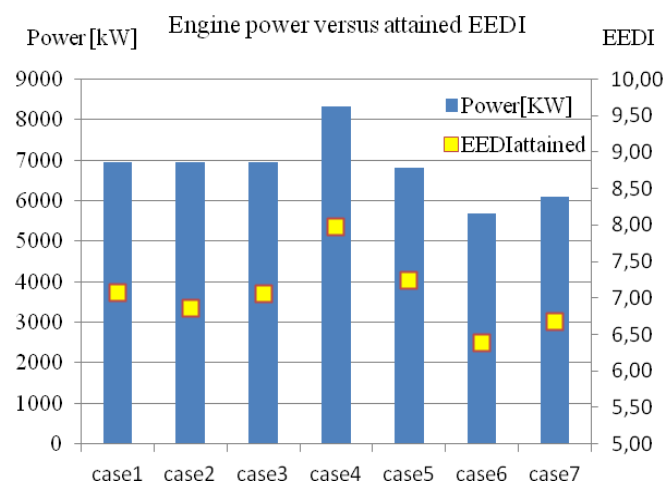

Fig.10. Engine power versus EEDI

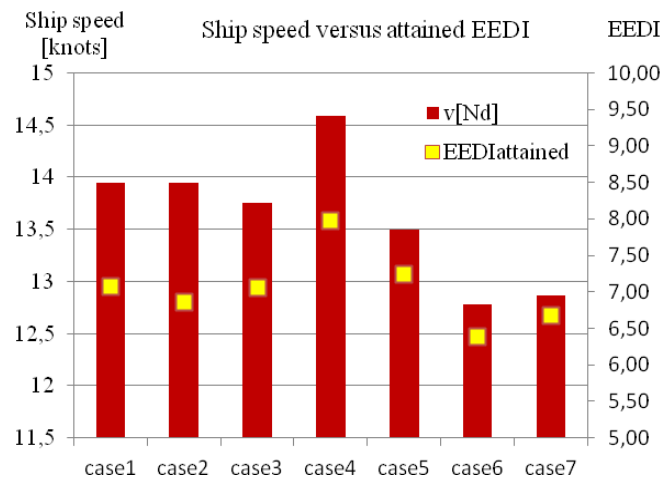

Fig.11. Ship speed versus EEDI

In this preliminary stage of the propulsive performance evaluation for a 30000 oil tanker, taking into considerations the EEDI regulations, the EEDI requirements have not been meet. This proves once again that EEDI has become a real challenge for a naval ar- chitect, representing an important tool in ship propulsion system design. For the study ship, in the next stage, solutions to reduce the index will be sought by looking for new optimum engine/propeller combinations, by improving ship hydrodynamics forms and decreasing the structural mass.

\section{CONCLUDING REMARKS}

The paper presents an evaluation of the propulsive performance for a 30000-tdw oil tanker, complying with the EEDI regulations. Several combinations main engines/optimal efficiency propeller have been analysed, but, in this preliminary stage, the propulsion performances could not be met simultaneously with the EEDI demands. This entails continuous efforts to improve ship design process, to fulfil all the requirements related to the performances of a new ship: large cargo capacity, minimum fuel consumption with low emissions, maximal speed performances.

\section{Acknowledgements}

The present research has been performed within the framework of the Naval Architecture Research Centre from the Naval Architecture Faculty of Galați.

\section{REFERENCES}

[1]. Omer, N., Comer, B., et all, "Green house Gas Emissions from Global Shipping, 20132015", International Council of Clean transport Report, www.theicct.org/publications.

[2]. International Maritime Organization, "2014,2018 Guidelines on the method of calculation of the Energy Efficiency Design Index (EEDI)for new ships", 2014, 2018

[3]. International Maritime Organization, "Procedure for calculation and verification of the Energy Efficiency Design Index (EEDI)",2013

[4]. Marine Engines Programme, Man Engines Solutions, $2^{\text {nd }}$ Edition. 2019, https://marine. man-es.com/marine-engine-programme

Paper received on November $9^{\text {th }}, 2019$ 